\title{
IDENTIFIKASI KEBUTUHAN INPUT PRODUKSI PADA USAHA BUDIDAYA IKAN LELE (Clarias sp) DI KABUPATEN BOYOLALI
}

\author{
Nensyana Shafitri dan Rani Hafsaridewi \\ Balai Besar Penelitian Sosial Ekonomi Kelautan dan Perikanan \\ JI. KS. Tubun Petamburan VI Jakarta 10260 \\ Telp. (021) 53650162, Fax. (021)53650159 \\ e-mail: nancy_kla10@yahoo.com \\ Diterima 3 Oktober 2012- Disetujui 27 November 2012
}

\begin{abstract}
ABSTRAK
Komoditas ikan lele (Clarias sp) menjadi komoditas unggulan program minapolitan di Kabupaten Boyolali. Dalam pengelolaan budidaya ikan lele perlu diperhatikan faktor-faktor input produksi untuk mengoptimalkan capaian produksi yaitu kolam atau lahan, benih/bibit, pakan, tenaga kerja dan permodalan. Makalah ini untuk mengidentifikasi kebutuhan input produksi dan permasalahan pemenuhan kebutuhan input produksi budidaya ikan lele di Kabupaten Boyolali. Survey dilakukan di kawasan minapolitan Kabupaten Boyolali. Data primer diperoleh dengan wawancara melalui pengisian kuesioner dengan informan kunci (key informan) yaitu pembudidaya dan petugas yang membidangi bidang perikanan. Data sekunder didapat dari hasil publikasi lembaga-lembaga yang terkait. Data dianalisis menggunakan metode deskriptif kualitatif. Berdasarkan hasil kajian dapat disimpulkan (1) terdapat kesesuaian media/wadah budidaya dengan komoditas yang dikembangkan (2) input produksi benih dan pakan diperoleh dari luar Kabupaten Boyolali (3) keterlibatan tenaga keja dalam berbagai kegiatan usaha budidaya ikan lele dan bantuan permodalan telah menjangkau pembudidaya. Upaya yang dilakukan untuk mengatasi permasalahan dalam pemenuhan kebutuahn input produksi adalah pengembangan kelembagaan input benih dan pakan. Pengembangan kelembagaan input benih dapat dilakukan per skala usaha. Pengembangan kelembagaan input pakan, dapat didorong untuk menjadi produsen dan pemasar pakan ikan buatan berbahan baku lokal. Pelatihan dan pendampingan pembuatan pakan ikan berbahan baku lokal.
\end{abstract}

Kata kunci: input, produksi, lele dan Boyolali

\section{Abstract : Identification of Production Input Needs on Catfish (Clarias Sp) Aquaculture in Tegal Regency By : Nensyana Shafitri and Rani Hafsaridewi.}

Catsfish (Clarias sp) commodities is a potential commodity in Boyolali Regency.To optimize catfish production, the farmers should consider the factors of production inputs, such as production areas/ponds, seed, labor and capital. This paper is to identify input production needs and problems of production input needs of catfish aquaculture in Boyolali Regency. Survey conducted in minapolitan areas of Boyolal Regency.The primary data ontained by interview through questionnaires with key informants and officer in charge of the fisheries. Secondary data obtained from the publication of related institutions. Data were analyzed by descriptive qualitative method. Based on the results of this study, the conclusion are (1) the ponds was suitable to the commodity, (2) Seed and feed was supplied from other district, (3) labor involvement in various business of catfish aquaculture activities and capital assistance has reached the farmers. To overcome the problem of production inputs are developing institutional of seed and feed inputs. Institutional development can be done by seed input scale. Institutional development of feed inputs, can be encouraged to become a manufacturer and marketer of artificial fish feed that made from local raw. Training and mentoring the manufacture of fish feed made from local raw material.

Keywords : input, production, catfish and Boyolali

\section{PENDAHULUAN}

Program minapolitan yang dicanangkan oleh Kementerian Kelautan dan Perikanan (KKP) sebagai upaya dalam mendorong pengembangan kawasan budidaya di daerah untuk meningkatkan perekonomian dan pertumbuhan wilayah dengan kegiatan perikanan budidaya sebagai motor penggerak utamanya. Program minapolitan menjadi sebuah kebijakan dalam pengembangan kawasan di perdesaan. Hal ini dilakukan untuk mengurangi kesenjangan antara kawasan perkotaan dan perdesaan serta kemiskinan di perdesaan, karena minapolitan adalah pembangunan perdesaan dengan infrastruktur setara kota yang tumbuh berkelanjutan sebagai sistem produksi berbasis komoditas KP unggulan lokal, berorientasi pasar, serta memiliki keterkaitan fungsional dan hierarki keruangan dalam satuan sistem minabisnis dan permukiman. (BBRSEKP, 2010). Program minapolitan telah ditetapkan dalam Peraturan Menteri Kelautan dan Perikanan Republik Indonesia Nomor Per 12/MEN/2010 tentang minapolitan.

Lebih lanjut, sebagai konsep pembangunan kelautan dan perikanan yang berbasis wilayah, minapolitan telah menempatkan Boyolali sebagai salah 
satu sentra lele terpadu di tanah air. Untuk memacu produksi perikanan budidaya, KKP telah menetapkan 10 komoditas unggulan dan lele merupakan salah satu komoditas unggulan tersebut. Produksi lele akan dipacu, dari 273.554 ton pada tahun 2010 menjadi 900 ribu ton pada tahun 2014 (Mudho, 2011). Penelitian ini dilaksanakan di Kabupaten Boyolali Provinsi Jawa Tengah yang berdasarkan penilaian dari Direktorat Jenderal Perikanan Budidaya yang sudah tercantum dalam surat keputusan menteri kelautan dan perikanan Republik Indonesia No. Kep. 32/MEN/2010 tentang penetapan kawasan minapolitan dengan tipologi kolam dan komoditas ikan lele. Kabupaten Boyolali merupakan salah satu kawasan Minapolitan percontohan untuk tahun 2011 yang berbasiskan pada komoditas unggulan lele, bersama Kabupaten Bogor dan Gunung Kidul.

Dalam usaha perikanan budidaya, tujuan pembudidaya adalah memaksimalkan keuntungan usaha. Perolehan keuntungan usaha budidaya ikan berkaitan dengan input produksi dan faktor produksi adalah semua biaya yang diberikan pada ikan lele agar ikan lele tersebut mampu tumbuh dan menghasilkan keuntungan. Faktor produksi dikenal dengan istilah input, production factor dan biaya produksi. Dalam berbagai pengalaman, menunjukkan bahwa faktor produksi lahan, modal untuk membeli bibit, pupuk, pakan, tenaga kerja dan aspek manajemen adalah faktor produksi yang terpenting diantara faktor produksi yang lain (Soekartawi, 2003).

Saat ini perkembangan budidaya ikan lele (Clarias $s p)$ berkembang pesat, namun jika tidak didukung dengan pengelolaan usaha budidaya yang baik menyebabkan penurunan kualitas. Untuk mencapai usaha budidaya yang efisiensi pada usaha budidaya ikan lele, baik efisiensi teknis, efisiensi harga maupun ekonomis diperlukan kombinasi dari penggunaan faktorfaktor produksi. Oleh karena itu, tujuan penulisan makalah ini adalah mengidentifikasi kebutuhan input produksi dan permasalahan pemenuhan kebutuan input produksi budidaya ikan lele di Kabupaten Boyolali. Hal ini perlu dilakukan untuk memaksimalkan keuntungan yang diperoleh dengan memperhatikan langkah-langkah sistematis budidaya dalam manajemen budidaya ikan.

Data primer diperoleh dengan wawancara melalui pengisian kuesioner dengan informan kunci (key informan) yaitu pembudidaya dan pejabat dari Dinas Petetnakan dan Perikanan. Data sekunder diperoleh dari hasil publikasi lembaga-lembaga terkait seperti Laporan Tahunan Dinas Kelautan dan Perikanan, Badan Perencanaan Daerah, dan lembagalembaga lain yang mendukung. Selanjutnya data dianalisis menggunakan strategi deskriptif kualitatif untuk menjelaskan keadaan dan gejala yang terjadi dari pengamatan di daerah penelitian.

\section{Gambaran Usaha Budidaya Ikan Lele}

Pusat pengembangan minapolitan di Kabupaten Boyolali dengan komoditas ikan lele (Clarias sp) di tentukan di Kecamatan Sawit, Banyudono dan Teras menjadi kawasan minapolitan. Kecamatan Sawit menjadi pusat pengembangan kawasan minapolitan bersama Kecamatan Banyudono serta Kecamatan Teras yang menjadi wilayah pendukung (hinterland).

Kecamatan Sawit memiliki sentra budidaya pembesaran ikan lele dengan luas lahan yang digunakan mencapai \pm 20 Ha dengan jenis ikan lele yang dikembangkan adalah lele dumbo (Clarias gariepinus). Komoditas lele dumbo banyak dikembangkan oleh pembudidaya di Kabupaten Boyolali dibandingkan dengan lele lokal dikarenakan ikan lele dumbo mempunyai pertumbuhan cepat, jumlah telur lebih banyak dan lebih tahan terhadap penyakit. Dalam rencana pengembangan Minapolitan Kabupaten Boyolali, Kampung Lele diprioritaskan menjadi sentra pembesaran ikan lele, dan Kecamatan Banyudono serta Kecamatan Teras menjadi kawasan sentra pembenihan.

Mata pencaharaian di bidang perikanan merupakan pekerjaan utama mayoritas masyarakat di Desa Tegalrejo dengan pengalaman usaha yang sudah rata-rata diatas 10 tahun. Alasan utama sebagian besar masyarakat melakukan budidaya ikan lele antara lain adalah perputaran uang untuk usaha budidaya ikan lele lebih cepat dan kecenderungan pola makan masyarakat yang bergeser pada bahan pangan yang sehat dan aman sehingga menjadi pemicu peningkatan permintaan ikan termasuk ikan lele.

Pola budidaya pembesaran ikan lele di Kecamatan Sawit secara umum dilakukan secara intensif dengan menggunakan kolam tanah dan pemupukan secara alami. Pakan yang digunakan adalah pakan buatan (pakan tenggelam dan pakan terapung) dengan pemberian pakan sehari dua kali, pagi dan sore hari.

Ukuran kolam budidaya bervariasi namun ukuran kolam yang optimal adalah $4 \mathrm{~m}$ x $15 \mathrm{~m}$. Kolam dengan ukuran optimal lebih efisien dan efektif dalam pemeliharaan, panen dan pengangkutan. Lama pembesaran ikan lele hingga siap panen rata-rata memerlukan waktu 3 - 4 bulan, sehingga dalam satu tahun dapat menghasilkan $3-4$ kali panen. Namun pada saat ini karena banyaknya faktor eksternal yang mempengaruhi usaha, lama pemeliharaan ikan lele menjadi semakin bertambah menjadi 6 bulan sehingga dalam satu tahun hanya 2 kali panen.

\section{Identifikasi Input Produksi Budidaya Ikan Lele}

Sistem produksi meliputi input, proses dan output. Input merupakan sumberdaya yang digunakan dalam proses produksi. Proses merupakan cara yang digunakan untuk menghasilkan produk dan output 
merupakan produk yang ingin dihasilkan (Setiawati, 2006). Pada usaha budidaya ikan lele di Kabupaten Boyolali teridentifikasi input produksi yang terdiri dari :

\section{Lahan Kolam}

Kolam yang digunakan oleh sebagian besar pembudidaya untuk usaha budidaya pembesaran adalah kolam tanah, meskipun terdapat beberapa pembudidaya menggunakan kolam beton. Menurut pembudidaya, ikan lele yang dibudidayakan di kolam tanah memilik daya tahan tubuh yang lebih kuat dan tidak berlemak. Berbeda dengan ikan lele yang dibudidayakan pada kolam beton menghasilkan daging yang berlemak dan tidak tahan terhadap penyakit. Namun demikian kolam tanah mempunyai kekurangan yaitu mudah mengalami kebocoran yang disebabkan karena ikan lele memiliki sifat menggali tanah. Di lain pihak, kolam beton dapat bertahan untuk jangka waktu yang lama karena dinding kolam tidak mudah bocor, mudah dalam penanganan dan pembersihan kolam.

Lahan yang digunakan oleh pembudidaya pada awalnya merupakan lahan sawah dan saat ini telah banyak beralih fungsi menjadi kolam ikan dengan status kepemilikan kolam milik sendiri dan sewa. Mengingat potensi lahan di sentra minapolitan Kecamatan Sawit seluas $20 \mathrm{Ha}$, memungkinkan untuk berkembangnya usaha budidaya ikan lele baik sistem sewa atau membeli tanah. Lahan sawah di Kecamatan Sawit menjadi kolam budidaya yang baik untuk pertumbuhan ikan lele dan hal ini sesuai dengan persyaratan pemilihan lokasi dimana tanah yang baik untuk kolam pemeliharaan ikan lele adalah jenis tanah liat/lempung, tidak berporos, berlumpur dan subur. Lahan tersebut dapat berupa; sawah, kecomberan, kolam pekarangan, kolam kebun dan blumbang (Arifin, 1991).

Hal lain yang terkait dengan lahan budidaya diantaranya kedekatan lokasi budidaya dengan sumber air sungai. Sumber air sungai menjadi salah satu faktor yang dapat menjamin keberlangsungan usaha budidaya dan menurut Nugroho (2007) sumber air sungai paling baik digunakan karena banyak mengandung bahan organik yang sangat dibutuhkan oleh ikan lele. Faktor lain yang perlu mendapatkan perhatian dari pembudidaya adalah kolam tidak terletak di tempat yang rentan ancaman banjir dan ramai lalau lalang aktivitas manusia. Menurut pembudidaya, lokasi budidaya di Kecamatan Sawit tidak termasuk dalam wilayah banjir dan mudah dijangkau pembudidaya. Kondisi ini membantu memudahkan pembudidaya untuk mengontrol kegiatan sehari hari yang bertujuan untuk mengurangi kebocoran. Kebocoran yang sering terjadi pada budidaya lele adalah penggunaan pakan yang tidak tercatat secara cermat (Nugroho, 2007). Berdasarkan hal-hal tersebut diatas, lahan usaha budidaya mempunyai kesesuaian dengan yang dipersyaratkan dalam budidaya ikan lele.

\section{Benih/Bibit}

Keberhasilan bisnis perikanan budidaya (akuakultur) tidak lepas dari ketersediaan benih ikan. Benih ikan merupakan awal dari suatu proses budidaya dan oleh karena itu kualitas benih ikan harus benarbenar bagus. Dengan kata lain, mutlak diperlukan suatu jaminan yang menyatakan bahwa kondisi benih suatu ikan sesuai standar benih yang berkualitas ketika akan digunakan dengan jaminan yang tertulis atau bersertifikat. (Husen, 2012).Terkait dengan benih lele yang digunakan oleh pembudidaya di Kabupaten Boyolali sebagian besar tidak berasal dari lokal Kabupaten Boyolali. Kabupaten Tulungagung dan Kabupaten Kediri menjadi pemasok utama untuk kebutuhan input produksi benih lele. Meskipun Kecamatan Teras dan Banyudono ditetapkan kawasan penyangga pembenihan lele, unit pembenihan rakyat (UPR) yang berada di lokasi tersebut belum mampu menjadi pemasok benih untuk kawasan pembesaran.

Hal tersebut disebabkan keterbatasan UPR lokal untuk memproduksi benih ikan dengan ukuran yang dipersyaratkan, belum terpenuhinya kesinambungan atau kontinuitas pasokan dan adanya persaingan harga antara benih ikan lele lokal Kabupaten Boyolali dengan Kabupaten Tulungagung atau Kabupaten Kediri. Ukuran benih ikan lele yang dipersyaratkan pembudidaya adalah benih berukuran antara $7-8 \mathrm{~cm}$ dengan harga ratarata antara Rp.75 - 100/ekor, sementara ketersediaan ukuran benih ikan lele dari UPR lokal Kabupaten Boyolali antara 5-6 cm dan jika tersedia benih ikan lele dengan ukuran 7-8 cm harga yang ditawarkan diatas Rp 100/ ekor. Tingginya permintaan kebutuhan benih lele untuk Kabupaten Boyolali dan sekitarnya menjadikan pembenih akan menjual benih ikan lele dengan ukuran dibawah $7 \mathrm{~cm}$.

Saat ini produksi pembenihan ikan lele di Kabupaten Boyolali dalam setiap bulannya hanya mampu memproduksi 5,3 juta benih (tabel 1), sementara kebutuhan benih yang diperlukan 6.000.000 ekor. Belum optimalnya produksi ikan lele memberikan peluang usaha yang menjanjikan. Siklus usaha pembenihan ikan lele yang relatif pendek sekitar 1,5 2 bulan menyebabkan perputaran uang menjadi lebih cepat diharapkan dapat menjadi pendorong untuk pengembangan usaha pembenihan ikan lele.

Pola budidaya pembenihan ikan lele di Kabupaten Boyolali pada umumnya dilakukan secara tradisional dengan sistem pemijahan alami. Pemijahan alami dilakukan dengan cara memilih induk jantan dan betina yang benar-benar matang gonad kemudian dipijahkan secara alami dalam bak/wadah pemijahan dengan pemberian kakaban/ijuk (Sunarma, 2004). Benih ikan lele dapat dipelihara di kolam tanah, kolam beton atau kolam yang dindingnya beton dengan dasarnya tanah (Khairuman dan Amri, 2002)dan para pembenih di Kabupaten Boyolali sebagian besar menggunakan kolam beton sebagai media pembenihan. 
Tabel 1. Kelompok Unit Pembenihan Rakyat Lele Kabupaten Boyolali Tahun 2009.

\begin{tabular}{llc}
\hline \multicolumn{1}{c}{ Nama Pokdakan } & \multicolumn{1}{c}{ Lokasi } & Rata-Rata Produksi/Bulan (Ton) \\
\hline Bangun Mina Tani & Desa Bendan, Kecamatan Banyudono & 323.000 \\
Mina Karya Muda & Desa Ketaon, Kecamatan Teras & 400.000 \\
Tani Mulyo & Desa Blagung Bendan, Kecamatan Banyudono & 345.000 \\
Kedung Lele & Desa Bendungan, Kecamatan Simo & 1.680 .000 \\
Mina Jaya Makmur & Desa Mudal, Kecamatan Boyolali & 365.000 \\
Mina Asih Pambudi & Desa Guwokajen, Kecamatan Sawit & 520.000 \\
Mina Maju & Desa Karang Kepoh, Kecamatan Karanggede & 11.000 \\
Mina Sejahtera & Desa Keongan, Kecamatan Nogosari & 324.000 \\
Candiri Mandiri & Desa Kiringan, Kecamatan Boyolali & 175.000 \\
Perintis & Desa Mudal, Kecamatan Boyolali & 740.000 \\
Patil & Desa Mudal, Kecamatan Boyolali & 76.000 \\
Mina Sari Mulyo & Desa Tanjungsari, Kecamatan Banyudono & 302.500 \\
Minasari & Desa Blagung, Kecamatan Simo & 47.250 \\
\hline
\end{tabular}

Sumber : Dinas Peternakan dan Perikanan Kabupaten Boyolali, 2010

\section{Pakan}

Pakan sebagai salah satu persyaratan yang harus diperhatikan baik kualitas maupun kuantitas, karena pakan mempunyai peranan penting dalam kegiatan budidaya. Usaha budidaya ikan yang semakin intensif menuntut tersedianya pakan dalam jumlah yang cukup, tepat waktu dan berkesinambungan. Fungsi utama pakan adalah untuk kelangsungan hidup dan pertumbuhan (Tahapari, 2012). Pada usaha budidaya ikan lele, teridentifikasi pakan yang digunakan oleh pembudidaya di Desa Tegalrejo adalah pakan buatan pabrik. Kandungan nutrisi yang memadai menjadi alasan pembudidaya menggunakan pakan pabrikan untuk memenuhi target panen.

Input pakan yang diperoleh pembudidaya berasal dari pedagang pakan dan hubungan ini membentuk ikatan ekonomis. Ikatan ekonomis menjadi bentuk jalinan kerjasama, dimana dengan menjalin kerjasama antar pengusaha atau lembaga lainnya pembudidaya akan mendapatkan informasi seputar usaha, pemenuhan kebutuhan produk maupun mencari pangsa pasar (Saparianto, 2009). Kepastian pasar bagi pembudidaya diperoleh dari pedagang pakan langganan yang juga bertindak pedagang pengumpul. Jalinana kerjasamanya lainnya terkait dengan pakan, terjadi antara pedagang pakan dengan pabrik pakan. Kebutuhan pakan yang mendominasi dalam usaha budidaya ikan, menjadikan pabrik pakan memberikan harga yang kompetitif. Untuk mendapatkan harga yang kompetitif pedagang pakan membentuk ikatan dengan salah satu pabrik pakan. Pemasok utama pakan ikan di Kabupaten Boyolali berasal dari Jakarta dan Surabaya.

Kebutuhan pakan ikan menjadi bagian yang mendominasi dapat dijelaskan sebagai berikut : rata-rata biaya pakan yang diperlukan untuk usaha skala mikro sebesar Rp. 96.571.429,- per siklus, sementara untuk skala usaha kecil adalah Rp. 297,953,846 per siklus dan pada skala usaha menengah adalah Rp. 409,000,000,- per siklus. (Purnomo et al, 2010). Besarnya biaya yang harus dikeluarkan untuk pengadaan pakan terutama untuk budidaya intensif dapat mencapai $60 \%$ dari biaya produksi (Afrianto dan Evi, 2005). Oleh karena itu pemberikan jumlah pakan, frekwensi pemberian pakan dan waktu yang tepat dalam pemberikan pakan pada ikan setiap harinya mempunyai pengaruh yang sangat besar terhadap pertumbuhan dan kelangsungan hidup ikan (Tahapari, 2012) dan hasil produksi berbanding lurus dengan biaya pakan yang telah dikeluarkan.

Frekunesi pemberian pakan oleh pembudidaya dilakukan sehari dua kali yaitu pagi dan sore hari dengan jenis pakan yang digunakan adalah pakan tenggelam dan pakan terapung. Menurut Purnomo et al (2010), konversi pakan atau Feed Convertion Ratio (FCR) di Kampung Lele Kecamatan Sawit menunjukkan antara 1 : 1,172,2 yang artinya setiap pemberian pakan 1,17-2,2 Kg menghasilkan $1 \mathrm{Kg}$ daging lele. Dalam praktek budidaya ikan lele tidak diperlakukan dengan menggunakan pakan tambahan seperti limbah peternakan ayam atau makanan yang tidak layak konsumsi. Pemberian pakan tambahan tidak diberikan dengsn alasan higienitas. Jika pemberian pakan tambahan tetap dilakukan, pembudidaya perlu diperhatikan higienis pakan, cara pemberian dan penyimpanannya agar transmisi parasit dan penyakit tidak terjadi pada hewan budidaya (Bank Indonesia, 2010).

\section{Tenaga Kerja dan Permodalan.}

Mayoritas masyarakat khususnya di Kampung Lele memperoleh pendapatan dari kegiatan perikanan. Jenis pekerjaan dalam budidaya ikan lele yang melibatkan banyak tenaga kerja adalah tenaga kerja pemeliharaan, persiapan kolam, panen, pemasaran dan perdagangan sarana produksi perikanan. Biaya tenaga kerja yang dikeluarkan oleh pembudidaya meliputi tenaga kerja pemeliharaan dan persiapan kolam sedangkan tenaga kerja panen pada umumnya disediakan oleh pembeli/ pedagang. 
Merujuk pada buku Pola Pembiayaan Usaha Kecil (PPUK) Pembenihan Ikan Lele yang dikeluarkan oleh Bank Indonesia (2010), menyatakan tenaga kerja yang terlibat dalam usaha pembenihan ikan lele dumbo di Kabupaten Boyolali umumnya hanya 1 orang per unit usaha dengan upah Rp 245.000 per bulan. Gaji perbulan diakumulasi dari beberapa kegiatan pembenihan, yaitu proses produksi/budidaya, pemeliharaan pompa dan peneliharaan kolam. Pada umumnya tenaga kerja yang terlibat berasal dari keluarga sendiri. Secara umum tidak ada spesialisasi keahlian atau tingkat pendidikan minimum tertentu yang dibutuhkan oleh seorang pekerja yang terlibat dalam kegiatan usaha ini. Meskipun demikian, pengetahuan tentang karakteristik masa pertumbuhan ikan lele harus benar-benar dipahami oleh pembenih terkait dengan ukuran untuk pemindahan dari satu kolam ke kolam lainnya dan jenis pakan yang diberikan. Lebih jauh pemahaman ini akan membantu pembenih dalam meminimalkan tingkat kematian lele

Tenaga kerja yang dibutuhkan dalam kegiatan budidaya pembesaran ikan lele relatif tidak terlalu banyak. Pada saat pembangunan kolam beserta fasilitas pendukungnya relatif lebih banyak memerlukan tenaga kerja. Tenaga kerja untuk kegiatan budidaya ini dalam operasionalnya hanya membutuhkan 1-2 orang pekerja untuk satu unit usaha yang dilakukan secara berkesinambungan sepanjang tahun. Pekerja umumnya dibayar secara harian/mingguan ataupun bagi hasil. Pekerjaan yang dilakukan oleh tenaga operasional antara lain melaksanakan kegiatan membeli pakan, memberikan pakan ikan lele, melakukan pembersihan serta menjaga keamanan (Bank Indonesia, 2010). Upah yang diberikan selama 5 jam bekerja sebesar Rp 35.000/hari Meskipun telah mempunyai tenaga kerja, pengawasan oleh pemilik tetap dilakukan untuk menghindari kebocoran khususnya dalam hal pemberian pakan sehingga tidak menimbulkan terjadinya peningkatan biaya produksi.

Lebih lanjut, faktor produksi penting lainnya adalah permodalan. Terkait dengan permodalan usaha, pada awalnya modal usaha para pembudidaya ikan berasal dari modal sendiri. Namun seiring dengan peningkatan produksi pembudidaya dan perputaran uang yang cukup besar, kepercayaan dunia perbankan terhadap sektor perikanan mulai mengalami peningkatan. Berbagai usaha telah dilakukan olah pemerintah daerah (pemda) Kabupaten Boyolali melalui Dinas Peternakan dan Perikanan untuk menarik minat perbankan menggulirkan dana ke sektor perikanan. Wujud usaha yang dilakukan seperti pertemuan antar pelaku usaha dengan perbankan dan pencanangan "Kampung Lele" dengan produksi kurang lebih 7 ton/hari dan kepastian pasar. Nilai uang yang dipinjamkan oleh bank pemerintah maupun bank swasta mencapai ratusan juta untuk satu pembudidaya. Saat ini kemudahan dalam mengakses permodalan dirasakan oleh masyarakat perikanan. Kemudahan yang didapat tidak hanya mementingkan jumlah masyarakat yang dibantu tetapi juga nilai bantuan yang diperlukan. Untuk itu usaha perikanan budidaya di Kabupaten Boyolali harus dikembangkan ke arah yang lebih bankable.

Kondisi tersebut diatas pada umumnya berlaku untuk pembudidaya yang mempunyai usaha budidaya lele dalam skala usaha kecil ke atas ataupun yang juga mempunyai usaha sebagai agen pakan ikan. Berbeda halnya dengan pembudidaya yang mempunyai usaha skala mikro, akses permodalan diperoleh dari pedagang pengumpul yang mempunyai usaha sebagai agen pakan ikan. Permodalan yang diberikan berupa pinjaman input produksi pakan ikan, dengan bentuk pembayaran yang dilakukan oleh pembudidaya adalah dengan menjual hasil panen kepada pedagang pengumpul atau agen pakan.

\section{Analisis dan Penanganan Permasalahan Input Produksi Lele}

Input produksi yang masih menjadi permasalahan yang dihadapi oleh pembudidaya ikan lele adalah benih ikan lele dan pakan. Input benih menjadi kendala karena benih harus didatangkan dari luar Kabupaten Boyolali. Hal ini menyebabkan kualitas benih ikan lele tidak dapat dikontrol oleh pembudidaya di Kabupaten Boyolali Pengiriman benih dari Kabupaten Tulungagung ke Kabupaten Boyolali kurang lebih berjarak $242 \mathrm{KM}$ atau setara dengan waktu tempuh antara 4-5 jam. Dalam usaha budidaya perikanan, untuk mendapatkan benih berkualitas diperoleh dari induk yang berkualitas untuk menjamin keberhasilan pembesaran sampai mencapai ukuran konsumsi. Menurut Sunarma (2004), ketersediaan benih untuk proses pembesaran tidak lepas dari ketersediaan induk yang berkualitas.

Permasalahan pembenihan dapat diatasi dengan pengembangan kelembagaan input benih. Kelembagaan input benih dikembangkan per unit skala usaha yaitu larva, pendederan I, pendederan II, pendederan III dan pendederan IV. Penguatan kelembagaan input benih dimaksudkan agar benih yang dihasilkan mempunyai kualitas yang baik sesuai dengan Standar Nasional Indonesia (SNI) 01.6484.2.2000 tentang Induk Ikan Lele Dumbo (Clarias gariepinus $x$ C. fuscus) Kelas Induk Pokok (Parent Stock). Menurut SNI kualitas benih ikan lele dumbo yang dijual terstandar menurut umur, panjang dan bobot minimal.

Tingginya harga input pakan juga menjadi permasalahan bagi pembudidaya di Kabupaten Boyolali. Kenaikan harga pakan tidak diimbangi secara signifikan dengan kenaikan harga jual ikan lele sehingga mengakibatkan biaya produksi terus mengalami peningkatan. Jika hal ini terus terjadi dapat memberikan dampak tidak optimalnya produksi budidaya ikan lele. Upaya yang dapat dilakukan adalah mengintroduksikan teknologi pakan ikan buatan berbahan baku lokal dengan memperhatikan kandungan gizi dan nutrisi. Selain itu, 
penguatan kelembagaan input pakan dapat dibentuk sebagai sarana introduksi yang dapat didorong untuk menjadi produsen dan pemasar pakan ikan buatan berbahan baku lokal.

\section{KESIMPULAN DAN SARAN}

Berdasarkan hasil pembahasan tersebut diatas, teridentifikasi kebutuhan input produksi dalam budidaya ikan lele di Kabupaten Boyolali yang terdiri dari :

1. Lahan kolam. Lahan budidaya yang digunakan mempunyai kesesuaian dengan media budidaya ikan dan komoditas yang dikembangkan.

2. Benih ikan. Kebutuhan benih ikan lele telah terpenuhi namun tidak berasal dari UPR lokal Kabupaten Boyolali sehingga kualitas benih ikan lele tidak dapat dikontrol oleh pembudidaya

3. Pakan ikan. Kebutuhan pakan pabrik telah mencukupi namun adanya cenderung kenaikan harga dapat menjadi kendala bagi pembudidaya ikan lele karena hampir $60 \%$ biaya produksi ikan lele digunakan untuk pembelian pakan.

4. Tenaga kerja dan permodalan. Keterlibatan tenaga kerja dalam budidaya ikan lele membuat sektor perikanan menjadi salah satu tumpuan dalam perekonomian rumah tangga. Peningkatan produksi ikan lele mendorong perbankan untuk memberikan permodalan kepada pembudidaya.

Terkait dengan permasalahan yang dihadapi oleh pembudidaya, upaya yang dapat dilakukan dalam pemenuhan input produksi benih ikan lele dan pakan ikan adalah pengembangan kelembagaan input benih dan pakan. Aturan main dalam kelembagaan ditetapkan secara bersama, sehingga kelembagaan yang ada mempunyai daya tawar terhadap persaingan dari luar kelompok. Pengembangan kelembagaan input benih dapat dilakukan per skala usaha yaitu larva, pendederan I, pendederan II, pendederan III dan pendederan IV. Sedangkan pengembangan kelembagaan input pakan, dapat didorong untuk menjadi produsen dan pemasar pakan ikan buatan berbahan baku lokal. Pelatihan dan pendampingan pembuatan pakan ikan berbahan baku lokal menjadi penting untuk dilakukan kepada pembudidaya ikan lele dengan memperhatikan kandungan gizi dan nutrisi yang sesuai dengan kebutuhan ikan lele.

\section{DAFTAR PUSTAKA}

Afrianto, E dan E. Liviawaty. 2005. Pakan Ikan Pembuatan, Penyimpanan, Pengujian, Pengembangan. Penerbit Kanisius. Yogyakarta.

Arifin, M.Z. 1991. Budidaya lele. Dohara Prize. Semarang. Balai Besar Riset Sosial Ekonomi Kelautan dan Perikanan. 2010. Konsep Metodologi Riset/ Kajian Minapolitan. Balai Besar Riset Sosial Ekonomi Kelautan dan Perikanan. Jakarta.
Bank Indonesia. 2010a. Pola Pembiayaan Usaha Kecil (PPUK) Pembenihan Ikan Lele. Jakarta..

. 2010b. Pola Pembiayaan Usaha Kecil (PPUK) Syariah Budidaya Pembesaran Ikan Lele. Jakarta.

Husen, M. 2012. Pentingnya Benih Ikan Bersertifikat. Trobos Media Agribisnis Peternakan dan Perikanan Edisi 20 Desember 2012.

Kementerian Kelautan dan Perikanan. 2010. Rencana Strategis Kementerian Kelautan dan Perikanan Tahun 2010-2014. Kementerian Kelautan dan Perikanan. Jakarta.

2011. KKP Keluarkan Program Revolusi Biru. (http://www.kkp.go.id/index.php/ arsip/c/2240/ KKP-Keluarkan-ProgramRevolusiBiru/?category_id=19/02/201, diakses pada tanggal 28 Nopember 2011).

Khairuman dan K. Amri. 2002. Budidaya Lele Secara Intensif. Agro Media Pustaka.Jakarta.

Mudho, Y. 2011. Geliat Ekonomi Boyolali sebagai Kawasan Minapolitan. (http://www.kkp.go.id/index. php/arsip/c/5916/Geliat-Ekonomi-Boyolalisebagai-Kawasan-Minapolitan/?c=siaranpers\&category_id=34, diakses pada tanggal 28 Nopember 2011).

Nugroho E. 2007. Kiat Agribisnis Lele Panduan Teknis dan Non Teknis Pembenihan dan Pembesaran. Penebar Swadaya. Depok.

Purnomo, A.H., Y. Hikmayani, Hikmah, E. Reswati, M. Firdaus, H.M. Huda, C.W. Witomo, M.P. Putri, R. Triyanti dan A. Azizi. 2010. Riset Evaluasi Sosial Ekonomi Praktek Pengelolaan Budidaya. Laporan Teknis. Balai Besar Penelitian Sosial Ekonomi Kelautan dan Perikanan. Jakarta.

Saparianto C. 2009. Budidaya Ikan Di Kolam Terpal. Penebar Swadaya. Depok.

Setiawati. 2006. Analisis Pengaruh Faktor Produksi Terhadap Produksi Industri Pengasapan Ikan di Kota Semarang. Tesis. Universitas Diponegoro. Semarang.

Soekartawi.2003. Teori Ekonomi Produksi Dengan Pokok Bahasan Analisis Fungsi Cobb-Douglas. PT. Raja Grafinco Persadan. Jakarta.

Sunarma, A. 2004. Peningkatan Produkstifitas Usaha Lele Sangkuriang (Clarias Sp). Makalah Disajikan pada Balai Budidaya Air Tawar, Direktorat Jenderal Perikanan Budidaya, Departemen Kelautan dan Perikanan pada tanggal 14 Juli 2004. Sukabumi.

Tahapari, E. 2012. Pembuatan Pakan Ikan Berbahan Baku Lokal. Makalah disampaikan pada acara Pengawalan Teknologi Untuk Peningkatan Kapasitas 16-17 Oktober 2012. Balai Penelitian Pemuliaan Ikan. Sukamandi. Tidak dipublikasikan. 